\title{
To Wait or Not to Wait: Swiss EU-Membership as an Investment under Uncertainty*
}

\author{
Beat Spirig and Rolf Weder**
}

JEL-Classification: D81, F02, F55

Keywords: European integration, investment under uncertainty, EU-membership

\section{Introduction}

Many countries are faced with the decision of whether to become part of a regional supranational institution, be it in Europe, the Americas or in Asia. Some countries join when they are offered the opportunity, but others do not. With respect to Europe it may be quite surprising that after 50 years of European integration a small, economically highly developed and, with the rest of Europe, culturally deeply enrooted state in the centre of Europe is not a member of the European Union (EU). The question arises how to interpret the Swiss behaviour, given the fact that many economic studies came to the conclusion throughout the last decades that the country would overall have benefited from an EU-membership. Thus, the question is: "Will a country join the EU immediately if it is believed that the expected net benefit is currently greater than the expected cost of accession?" This is the main question we would like to address in this paper. Our answer will be: "not necessarily". The aim of this paper is thus to introduce a somewhat new perspective on the question of accession to the EU by applying the so-called 'theory of investment under uncertainty'. We argue that this

* Reports by two anonymous referees and advice by the editor are gratefully appreciated. We also benefited from comments by Hans Genberg, Matthias Hagman, Carsten Hefeker and Daniel Hoechle, by participants at the Annual Meeting of the Swiss Society of Economics and Statistics in March 2004 to an early version of this paper, by attendants of the conference on Swiss EU-membership at the University of Basel in February 2007 and by participants of the research seminar at the Department of Economics of the University of Winnipeg in April 2007. Beat Spirig acknowledges financial support from the WWZ-Forum and the Europainstitute.

** Authors' address: Faculty of Business and Economics and Europainstitute, University of Basel, Postfach, CH-4003 Basel, Switzerland. Email: beat.spirig@unibas.ch and rolf.weder@unibas. ch. 
approach, emphasized with a simplified model, helps to understand delayed EU accession, in general, and the Swiss case, in particular.

In Switzerland, there are mainly two opinions on the question of entry into the EU. On the one hand, there are the advocates of an accession. These exponents request an immediate entry, or at least immediate negotiations about an accession to the EU. ${ }^{1}$ On the other side, there are exponents who ask for pulling back the membership application deposited in Brussels in 1992. ${ }^{2}$ They are convinced that Switzerland should not - probably never - join the EU. The main argument of the "fast-accession fraction" is that the interests of Switzerland in Europe and vis-à-vis third countries can be better pursued as a member of the EU than as an outsider. The "never-accession fraction" argues the exact opposite. The situation seems to be deadlocked. "Are you in favour or against an entry in the EU?" has become a crucial question when thinking about the Swiss relationship to the EU. Given the historical record of Switzerland and of many other European countries, one can interpret the observed behaviour also as delayed EU accession. Thus, we propose to replace the described two questions by a slightly different type: "should a country decide to wait or not to wait regarding its accession to a supranational institution?”.

Several economic studies have been published over the last 15 years. These include the "Hauser-Report" for Switzerland (Hauser and BradKe, 1992) which, similar to the "Cecchini-Report" for the European Community (EC), projected an increase of the Swiss GDP by $4-6 \%$ in case of a Swiss membership to the European Economic Area (EEA) or to the EC. The Swiss Federal Council (1999), in turn, published the findings of additional studies in his integration report in $1999 .{ }^{3}$ Interestingly, these studies distinguished between two periods, a first period of economic adjustment with a negative effect of EU accession on Swiss GDP per capita and a second period with a long-term positive welfare effect on the Swiss economy. ${ }^{4}$ Interpreted from the perspective of an investment

1 This group recently asked the Swiss Federal Council to start the negotiations, but also to seek special treatment in a number of areas such as being allowed to stay outside of the Monetary Union (EMU); see the „Neue Europa-Plattform“ by the Socialist Democratic Party (2006), p. 196 or the assessment of the Green Party (see „Grüne wollen EU-Beitritt mit Spezialregelungen“, Neuer Zürcher Zeitung, 29.8.06, p. 11).

2 See Swiss People's Party (2005), p. 3.

3 Bärlocher, Schips and Stadler (1999) for KOF, Müller and Nieuwkoop (1999) for ECOPLAN, Vaterlaus et al. (1999) for BAK and Laboratoire d'ÉCONOMIE APPliquée (LEA) (1999). See also UBS (2000) which estimates further economic effects based on these studies.

4 This is particularly emphasized in the study by UBS (2000) which we will come back to in Section 4. 
decision for a whole country, these studies take an approach which fits the traditional investment theory that basically compares the discounted expected net benefits in future with the accession or adjustment costs in presence.

This traditional approach has, in our view, four shortcomings. First, this decision rule does not explicitly take into account that if a country once has joined the $\mathrm{EU}$, the decision is de facto irreversible. Note that irreversibility does not require that leaving the $\mathrm{EU}$ at a later point in time is impossible. It rather assumes that entry is costly and that these costs are sunk. Second, the decision rule does not fully and explicitly take into account that the future development of the benefits and costs is uncertain and that the degree of uncertainty may change over time. Third, it ignores the possibility to postpone an accession to the EU to a later point in time which, in principle, has a value and, therefore, should be considered. Finally, these studies do not explicitly consider political costs and benefits in addition to the well-analyzed economic costs and benefits even though political factors are obviously important when evaluating an accession to an institution such as the EU.

We believe a unified framework is currently lacking that eliminates the shortcomings of existing discussions and thus allows capturing the opportunities and risks of a membership in one setting. The theory of investment under uncertainty (Dixit and PINDYCK, 1994) applied to a whole country is, in our view, able to offer the required new perspective. It provides the rationale for a possible third position about EU-membership which proposes to wait in order to keep the option to join at a later stage if conditions turn out to be advantageous. Waiting thus incorporates a value. The value of this flexibility option may, however, become negative if, for example, an immediate accession is likely to provide considerable benefits that are foregone by a waiting country.

The idea is, of course, not entirely new. Dewatripont and Roland (1995) discuss the design of large-scale reform packages in transition economies that "involve great aggregate and individual uncertainty" (p. 1208). One of their conclusions is that under certain conditions a gradual approach to reform is preferred to a big-bang approach as it "generates a higher investment response because of a lower option value of waiting" (p. 1207). In contrast to this paper, we completely focus on the timing aspect of one strategy (i.e. accession) and we regard the decision of the government itself as an investment with uncertain economic and political costs and benefits. BEGG et al. (2003) discuss the economic consequences for U.K. of staying outside the European Monetary Union (EMU). Interestingly, the comprehensive study describes this decision as a "temporary delay" which is "an option with a price" (p.5) in the executive summary. However, this aspect is not fully developed in the study which mainly focuses on the 
benefits and costs of introducing the Euro without referring to the uncertainty itself. This contrasts with our paper that puts the value of waiting and its determinants at the centre of the analysis.

We find that our approach offers some insight regarding the behaviour of Switzerland vis-à-vis the EU during different phases of European integration. In particular, we show that the (sunk) accession costs are likely to be considerable for Switzerland due to, among others, its direct-democratic system. Moreover, the expected net annual pay-off of an EU-membership may well have fallen and the uncertainty seems to have increased during the last 15 years. Given the sunk accession costs, both of these aspects increase, as we will show below, the value of waiting. ${ }^{5}$ To a political economist our approach probably appears somewhat naïve as it assumes that a country's integration policy is largely guided by its national interest. An alternative approach would, of course, try to explain the integration policy of a country with the mere (expected) distributional effects of an EU-accession on potential losers and winners in the acceding country and analyse how these groups affect the decision in the political process. ${ }^{6}$ Note, however, that we would expect our approach also to be relevant on the individual group level as these groups are likely to make a cost-benefit analysis, also taking into account uncertainty. Moreover, it is possible that political competition between the national interest groups in a (direct) democracy may lead to an integration policy that is in line with overall national interest. If it does, it is at least interesting.

The remainder of the paper is structured as follows. Section 2 applies the option value of waiting approach to the issue of joining a supranational institution by presenting a simplified two-period model. Comparative statics results of the model are then derived in Section 3. Section 4 uses these results in order to evaluate the Swiss behaviour regarding EU accession. Section 5 considers alternative integration possibilities Switzerland encountered during the last few decades, and relates the findings to the experience of similar countries. Section 6 concludes.

5 Note that, in its latest report, the Swiss Federal Council explicitly describes an EU-accession as an "option" after having named it a "strategic target" for many years (see Swiss Federal Council, 2006, p. 6). This change of perspective would be consistent with our approach proposed in this paper.

6 See, for example, Baldwin (1994, p.68) for a general discussion and Brunetti, JaGgi and WedER (1998) for an empirical analysis of the Swiss people's vote against a participation in the European Economic Area in December 1992. 


\section{A Simple Two-Period Model of Accession}

We suppose that the accession of a country to a supranational institution such as the EU, firstly, requires an irreversible investment that, secondly, provides net annual benefits which are uncertain.

The first aspect of this interpretation is supported by HAUBRICH and RITTER (2004, p. 2) who state:

The decision to commit, however, is not an irrevocable choice made once and for all at the beginning of time. Instead, the policy choice is more like the decision to make an irreversible investment: The policymaker and/or society bears some political or economic adjustment cost, but once the policy is in place, this is a sunk cost and reversal is also costly.

In the case of the EU, for example, the costs of investment are associated with the adoption and implementation of the acquis communautaire, a corpus of approximately 100,000 pages of guidelines, bye-laws and laws. Adjusting a country's legal, political and economic framework to the requirements of EU membership has one-time costs - administrative costs of changing and implementing the laws and decrees, economic costs of adjusting the economy's structure to a change in prices, and political costs due to a change in the political system and its impact on the representation of people's preferences in politics. These costs are idiosyncratic to the membership and thus depend also on how a country would develop its framework in the case of non-membership. Note that the investment is irreversible or sunk in this approach because the investment costs incurred can not be recuperated if a country decides to exit the club at a later stage.

The second aspect of this interpretation is obvious: joining the EU leads to net annual benefits that are uncertain. Annual benefits may, for example, include economic gains from market integration (e.g. better access to the EU market) and political gains from a marginal effect on the decisions made in the EU institutions (e.g. bringing decisions closer to one's own preferences) or even from an image improvement to be part of the club. Annual costs arise because of, for example, yearly payments in the EU budget or the loss of seigniorage as a consequence of joining the European Monetary Union (EMU). An important point we want to emphasize is that the degree of uncertainty regarding the net annual benefits is likely to change over time. For example, the political gains from affecting the decisions in EU institutions depend on the development of the voting schemes or of the power of the various EU institutions. The economic gains of integration depend on the change of the size of the internal market (enlargement of the $\mathrm{EU}$ ) or of the quality of EU legislation. All these parameters have, of course, to 
be determined in relative terms, i.e. relative to a country's (changing) situation in case of non-membership.

Both aspects - irreversibility and uncertainty - imply that a country joining the EU today gives up the possibility of waiting for new information to arrive that could affect the desirability of joining the EU. Giving up this option is costly. The new information may relate to important aspects about the development of the supranational institution (e.g. the number of members, the change in the voting schemes) and of the outsider country (e.g. the likelihood of policy reforms in case of non-accession, alternative policy options). We now present a model that allows to study under which condition waiting is a preferred strategy in a country's decision of accession. The model is based on Dixit and PINDYCK (1994, pp. 26-30) and kept as simple as possible in order to achieve a good understanding and intuition of the crucial relationships.

Suppose a country plans to join a supranational institution. There exists an expected stream of net annual benefit, $E\left(V_{t}\right)$, which is constant and occurs in each period, $\mathrm{t}$, as soon as the country joins the institution. ${ }^{8}$ There is an investment, $I_{t}$, which is a one-time cost that is required in period t when a country commits to join the supranational entity. Let us first assume that the country is faced with the decision "to join now or never" in period $t_{0}$. In this case, a social planner should compare the expected net annual benefit, $E\left(V_{t}\right)$, over the period $t_{0}$ to $t_{\infty}$, discounted at the time preference $(i)$, with the accession costs $\left(I_{0}\right)$ in period 0 . Based on this (orthodox) approach, the country should be recommended to join the supranational institution if the net present value (NPV) in period 0 is positive. Thus,

$$
N P V=\left[-I_{0}+\sum_{t=0}^{\infty} \frac{E\left(V_{t}\right)}{(1+i)^{t}}\right]=-I_{0}+\frac{E\left(V_{t}\right)}{i}+E\left(V_{t}\right)>0 .
$$

As pointed out by McDonald and Siegel (1986) and developed by Dixit and Pindyck (1994) this decision rule is not sufficient if an investment can be postponed to period 1 . Note that the decision in equation (1) is based on the

7 An increase in the number of members raises the economic discrimination effects on outsiders as shown by BALDWIN (1995) in his "domino theory". Furthermore, some of the advantages of integration could, in principle, be captured independently of the accession if the country, for example, manages to strengthen its competition policy and liberalize the internal market as argued in the above mentioned Hauser-Report (HAuser and Bradke (1992, p. 259). Borner and Bodmer (2004, p. 223), however, consider this strategy as politically unfeasible in their analysis of the relatively weak growth performance of Switzerland during the 1990s.

8 We could also interpret $E(V)$ as the expected utility of a representative resident. 
expected values of $V_{t}$. In reality, however, $V_{t}$ may turn out to be lower or higher. In the most simple form, this uncertainty can be introduced by assuming that two states of the world are possible ("good" or "bad") associated with high $\left(V_{t}^{H}\right)$ or low $\left(V_{t}^{L}\right)$ net annual benefits. $V_{t}^{H}$ happens with probability $p$ and $V_{t}^{L}$ with probability $1-p$. To stress the main point we focus on the extreme case where the state of the world is fully revealed in period 1. Figure 1 gives an illustration of the described pay-offs and the timing.

Figure 1: Structure of the Two-Period Model

Net annual benefits

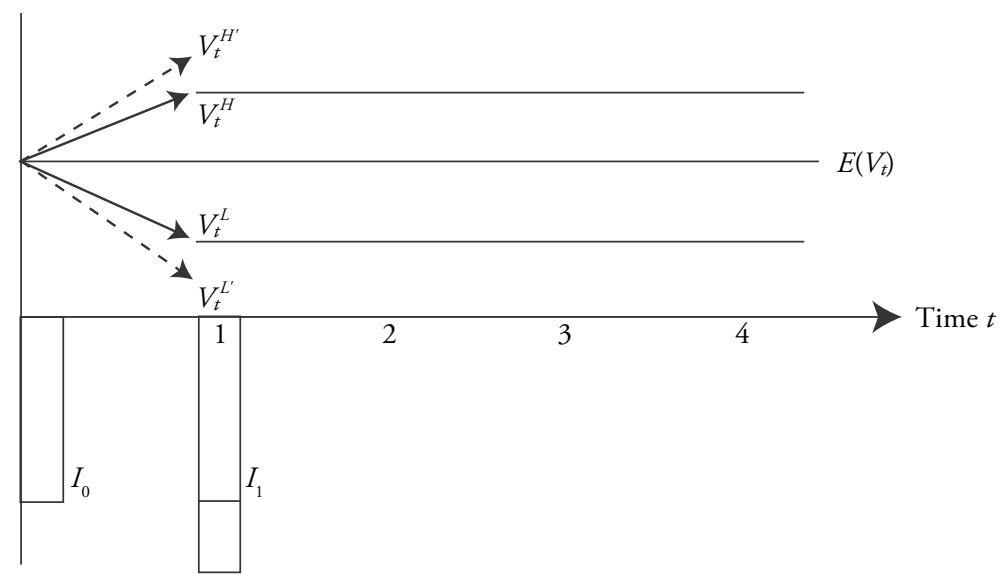

Cost of accession

Source: Own Figure.

Note that the explicit consideration of the two rather different states of nature that may occur in period 1 affect the behaviour of a country that has to make a decision in period 0 . If, in period $1, V_{t}$ turns out to be low $\left(V_{t}^{L}\right)$ permanently, the country may regret its decision made in period 0 . In other words, to wait until period 1 and to join only when $V_{t}$ is high $\left(V_{t}^{H}\right)$ may be the better decision to take in period 0 . We, again, calculate the net present value in period $0\left(N P V_{H}\right)$ of waiting until period 1 and joining the supranational institution in period 1 with accession costs $I_{1}$ if the good state of the world, $V_{t}^{H}$, is revealed in period 1 and thereafter. Thus, 


$$
N P V_{H}=p\left[\frac{-I_{1}}{1+i}+\sum_{t=1}^{\infty} \frac{V_{t}^{H}}{(1+i)^{t}}\right]=p\left[\frac{-I_{1}}{1+i}+\frac{V_{t}^{H}}{i}\right]
$$

In order to decide whether 'to wait or not to wait', the country has to compare the two net present values. A positive difference between $N P V_{H}$ and $N P V$ implies that there is a positive value to wait $(W>0)$. By subtracting (1) from (2) we find:

$$
W=N P V_{H}-N P V=p\left[\frac{-I_{1}}{1+i}+\frac{V_{t}^{H}}{i}\right]-\left[-I_{0}+\frac{E\left(V_{t}\right)}{i}+E\left(V_{t}\right)\right]
$$

If $W$ is positive waiting has a positive value which implies that the country should wait and join tomorrow if the good state of nature occurs. ${ }^{9} W$ is the value of this 'flexibility option'. Thus, it can be optimal to wait for a country if the future development is uncertain and the investment is irreversible. The intuition is that waiting to period 1 increases the information (in our simple model there is complete information in period 1). By waiting, the country gets the opportunity to join only if the good case realizes and to avoid becoming a member of the supranational institution in the bad case. As shown by equation (3) the value of waiting may also be negative which implies that the country is better off joining in period 0 .

Let us consider important aspects of this simplified approach. First, note that the sunkness of $I_{t}$ is important for this result because, otherwise, a country could join in period 0 based on its expectations and exit in period 1 if the bad case occurs and recuperate the accession costs. If, however, $I_{t}$ is sunk the country only faces this flexibility if it waits to join until period 1 . In fact, with $I_{t}$ being sunk the country would never exit in period 1 , even in the bad case, as long as $V_{t}^{L}$ is positive. Therefore, the key aspect of the assumption of the irreversibility of investment is not that a drop out of a supranational institution such as the EU would be impossible - we know that it is possible ${ }^{10}-$, but rather that entry is associated with costs that are sunk.

Second, note that the approach could explicitly take into account the possibility of an exit in period 1 . This becomes interesting if a country faces nega-

9 If we interpret $E\left(V_{t}\right)$ as the expected utility, the decision rule in equation (3) implies that the representative resident is risk neutral as $E\left(V_{t}\right)$ is calculated as the weighted average of $V_{t}^{H}$ and $V_{t}^{L}$.

10 Secession of the EU is possible (as the case of Greenland has shown in 1985), but also costly and uncertain (see Swiss Federal Council, 1999, p. 331). 
tive net annual benefits in the bad case, $V_{t}^{L}<0$, and relatively low exit costs in period $1 .^{11}$ In this case, equation (3) would overestimate the value of waiting as the accession in period 0 does not consider the possibility of an exit in period 1 in the bad case. Thus, $N P V$ in equations (1) and (3) has to be replaced by $N P V^{\prime}=-I_{0}+E\left(V_{t}\right)+p\left(V_{t}^{H} / i\right)$, assuming no exit costs. ${ }^{12}$ Thus, the value of waiting in equation (3) adjusts to

$$
W=N P V_{H}-N P V^{\prime}=-p \frac{I_{1}}{1+i}+I_{0}-E\left(V_{t}\right)
$$

Equation (4) implies that waiting may remain preferable even if exit in period 1 is possible and if there are no exit costs. This is more likely if the accession costs are high and the expected pay-off in period 0 is low. Thus, taking into account the possibility of exit does not fundamentally change the approach.

Third, it is interesting to note that the value of waiting, W, may be positive despite of the fact that the sunk cost of joining a supranational institution increases over time, as we will show below. This increase of the accession costs over time is illustrated in Figure 1 by the dotted bar representing $I_{1}\left(I_{1}>I_{0}\right)$.

Fourth, the assumption that more information regarding the state of nature is available in period 1 - in the model above it is fully revealed - is, of course, essential for the pursued approach. Note that if there is no additional information available in period 1 compared to period 0 , there is no reason to wait; the country should make its decision based on its best guess in period 0 . However, allowing some information to arrive without fully revealing the state of nature in period 1 would not fundamentally change the model's prediction, though make it much more complex to handle. Also note that countries that enter the supranational institution in period 0 are not assumed to learn more about the net benefits in period 1 than countries that stay outside.

Finally, we disregard the possibility that the expected annual benefits depend on whether the country waits until period 1 or not. Suppose, however, firms increase their private investment in period 0 only if the country credibly commits to enter the supranational institution. In this case, the expected net annual benefits would be different depending on whether a country decides to enter or to wait.

11 We thank an anonymous referee for making us aware of this point.

12 Note that the term $E\left(V_{t}\right) / i=p\left(V_{t}^{H} / i\right)+(1-p)\left(V_{t}^{L} / i\right)$ in equations (1) and (3) is replaced by $p\left(V_{t}^{H} / i\right)$ as the (negative) term $(1-p)\left(V_{t}^{L} / i\right)$ vanishes with the option of exit in case of $V_{t}^{L}<0$. 


\section{The Determinants of the Value of Waiting}

We now derive important comparative statics results. We determine how the degree of uncertainty, measured by the spread of the net annual benefits, as well as a change in the annual benefits affect the value of waiting, $W$, and then derive how $W$ depends on changes in the costs of accession $\left(I_{t}\right)$ and on the probability of the good state of nature to occur $(p) .^{13}$

\subsection{Uncertainty}

An increase in the degree of uncertainty can be studied by a mean-preserving increase of the spread of the net annual benefits, i.e. by an increase of $V_{t}^{H}$ and an according decrease of $V_{t}^{L}$ such that the expected net annual benefit, $E\left(V_{t}\right)$, stays the same. This exercise is shown in Figure 1 by the dotted arrows that lead to the net annual benefits $V_{t}^{H}$, and $V_{t}^{L}$, respectively. We take equation (3) and assume that the costs of entry do not change over time, i.e. $I_{0}=I_{1}=I$. Thus,

$$
\begin{aligned}
W & =p\left[\frac{-I}{1+i}+\frac{V_{t}^{H}}{i}\right]-\left[-I+\frac{E\left(V_{t}\right)}{i}+E\left(V_{t}\right)\right] \\
& =\left(1-\frac{p}{1+i}\right) I+\frac{p}{i} V_{t}^{H}-\frac{(1+i)}{i} E\left(V_{t}\right) .
\end{aligned}
$$

With an unchanged expected stream of net annual benefits, $E\left(V_{t}\right)$, equation (5) implies that the value of waiting increases with an increase in the degree of uncertainty: $\partial W / \partial V_{t}^{H}=p / i>0$. Thus, for each unit of additional net annual benefits in the good case $\left(V_{t}^{H}\right), \mathrm{W}$ rises by the annuity $(1 / i)$ of this unit multiplied by the probability $(p)$ of its occurrence. The rationale for this result is that an increase in uncertainty makes it more valuable for a country to wait and only to join if, in period 1 , the good state of nature occurs, thereby preventing being "captured" if the bad case occurs.

13 We disregard the derivation of the comparative statics with respect to the time preference (i) as this aspect will not be used in Sections 4 and 5. Also note that we do not consider the possibility of exit in period 1 . 


\subsection{Net Annual Benefits}

Equation (5) also shows that an increase in the expected net annual benefits $\left(\mathrm{E}\left(\mathrm{V}_{\mathrm{t}}\right)\right)$, leaving $V_{t}^{H}$ constant and raising $V_{t}^{L}$, reduces the value of waiting as $\partial W / \partial E\left(V_{t}\right)=-(1+i) / i<0$. The intuition is that waiting becomes less attractive as the negative effect of the bad state of nature is reduced; in other words, there is a smaller "downward risk". This result is, of course, consistent with the comparative statics result in Section 3.1. By increasing $\mathrm{E}\left(\mathrm{V}_{\mathrm{t}}\right)$ and leaving $V_{t}^{H}$ constant, we reduce the spread and thus the degree of uncertainty which reduces the value of waiting.

The question arises how an increase in $V_{t}^{H}$, ceteris paribus, affects the value of waiting. One could argue that this increases the spread of the annual benefits and thus should increase the value of waiting; on the other hand, it also increases the expected net annual benefit which reduces the value of waiting. In order to analyse we replace $\mathrm{E}\left(\mathrm{V}_{\mathrm{t}}\right)$ in equation (5) by its determinants:

$$
\begin{aligned}
W & =\left(1-\frac{p}{1+i}\right) I+\frac{p}{i} V_{t}^{H}-\frac{(1+i)}{i}\left[p V_{t}^{H}+(1-p) V_{t}^{L}\right] \\
& =\left(1-\frac{p}{1+i}\right) I-p V_{t}^{H}-\frac{(1-p)(1+i)}{i} V_{t}^{L} .
\end{aligned}
$$

Thus, it can easily be seen that an increase in $V_{t}^{H}$ reduces the value of waiting. The good case becomes better which relatively increases the expected net annual benefits of an immediate accession. The intuition is that, with an increase in $V_{t}^{H}$, the opportunity costs of waiting in terms of foregone net annual benefits in period 0 rise and thus make waiting less attractive.

Proposition 1 summarizes our findings in the Subsections 3.1 and 3.2:

Proposition 1: The value of waiting $(W)$ rises if the uncertainty regarding the future net annual benefits of accession - interpreted as the spread between the benefits in the good and the bad state of nature - increases and it falls with an increase in the expected net annual benefits. 


\subsection{Adjustment Costs}

We now determine how the value of waiting depends on changes in the costs of accession $\left(I_{t}\right)$, In order to do so, we determine the first derivative of $W$ with respect to $I$, still assuming that $I_{0}=I_{1}=I$. Equation (6) reveals that the value of waiting is raised as $\partial W / \partial I=(1-p /(1+i))>0$. The intuition of this result is that the accession becomes less beneficial and thus lowers the value of both strategies, immediate accession and possible accession in period 1. However, as can be seen by inspection of equation (5), $N P V_{H}$ decreases by a smaller extent because, first, the increase in $I$ is discounted and, second, enters only with the probability of the good case to occur. Therefore, it becomes more attractive to wait and, thus, only to commit to these higher investment costs if the good state of nature occurs. Note that we are considering a level effect here where both $I_{0}$ and $I_{1}$ increase by the same amount.

A different question is how the value of waiting depends on a dynamic change of the accession costs, i.e. a change of $I$ over time. Suppose the costs of accession rise from $I_{0}$ to $I_{1 .}$. In this case, waiting is "costly" in the sense that a country has to pay more to join the supranational institution if it delays accession. This does not inevitably mean that the value of waiting becomes zero or negative. The accession costs, $I_{1}^{*}$, that make a country indifferent between joining in period 0 and in period 1 , can be calculated. ${ }^{14} I_{1}^{*}$ has to take a value which equates $N P V_{H}$ and $N P V$ :

$$
N P V_{H}=p\left[\frac{-I_{1}^{*}}{1+i}+\frac{V_{t}^{H}}{i}\right]=N P V .
$$

If $I_{t}$ reaches $I_{1}^{*}$ the value of waiting, $W$, becomes zero. Note that a country may wait to enter a supranational institution despite of the fact that $I_{0}$ is expected to rise to $I_{1}$ as long as $I_{1}<I_{1}^{*}$. This occurs if the flexibility of the country to join later has a high value. On the other hand, if $I$ is likely to rise considerably between period 0 und period 1 , then the value of waiting might become negative which favours an immediate accession.

Proposition 2: The value of waiting $(W)$ is greater, the higher are the costs of accession $\left(I_{t}\right)$ to the supranational institution in period 0 and thereafter. However, an (expected) increase of the accession costs over time reduces the value of waiting.

14 This is also shown in Dixit and PIndyck (1994, p. 28). 


\subsection{Probability of the Good State of Nature}

We finally determine how the value of waiting depends on the probability of the good state of nature to occur. Based on equation (6) we find the following result for the first derivative of $W$ with respect to the probability, $p$ :

$$
\frac{\partial W}{\partial p}=-\frac{I}{1+i}-V_{t}^{H}+V_{t}^{L}\left(\frac{1+i}{i}\right)
$$

Equation (8) reveals that we cannot sign the first derivative in general. However, it can be shown that $W>0$ is a sufficient condition for $\partial W / \partial p<0$ (see the proof in the Appendix). In other words, the value of waiting decreases with an increase in $p$ if a country's value of waiting is currently positive. A higher probability of the good state of nature to occur makes it more attractive to join the supranational institution, in general, and thus reduces the value of the flexibility option. The reason for this result can be understood by inspection of equation (5): an increase of p implies that $N P V$ increases by more than $N P V_{H}$ due to the increased expected net annual benefits in period 0 .

Proposition 3: The value of waiting $(W)$ decreases with an increase in the probability of the good state of nature to occur, given that $W>0$.

Before we move to the empirical part of this paper, let us consider the fundamental trade-off of waiting. Note that we can explicitly decompose the value of waiting $(W)$ into a benefit-component and a cost-component. This can be shown by slightly reformulating equation (6):

$$
W=\left[I\left(1-\frac{p}{1+i}\right)\right]-\left[E\left(V_{t}\right)+(1-p) \frac{V_{t}^{L}}{i}\right]
$$

Thus, the value of waiting $(W)$ depends on two components, a benefit-component and a cost-component of postponing an accession. $W$ becomes negative if the benefit-component is smaller than the cost-component. The benefit-component captures the reduced accession costs due to postponing them (discounting with $i$ ) to period 1 and to only joining in the good state of nature $(p)$. The costcomponent of waiting is composed of the unrealized expected net annual benefits in period $0, E\left(V_{t}\right)$, and the expected value of the annuity of the net benefits 
in the bad case, $(1-p) V_{t}^{L} / i$. Equation (9) reveals that the value of waiting does take into account the cost associated with postponing an accession to the supranational institution.

\section{The Swiss Behaviour Regarding EU Accession}

The described framework should help to explain why some countries join the EU faster than others and, in particular, why a country like Switzerland seems to face a positive value of waiting. In the following, we interpret the Swiss case from the perspective of the four determinants of the value of waiting derived in Section 3.

\subsection{Economic and Political Adjustment Costs}

Proposition 2 states that countries with high economic and political costs of accession should join later.

The economic adjustment costs can indirectly be derived from the studies that captured the economic effects of a Swiss EU-membership and that were published in the Swiss integration report in 1999 (see Section 1). Figure 2 stylizes the bottom line of these studies. It shows the development path of Swiss welfare, for example approximated by GDP, for two cases, i.e. "Accession to EU" and "Continuation of Bilateralism" which describes the continuation of the current integration policy. The adjustment period is estimated to last between 8 to 15 years and is due to structural adjustments of the Swiss economy created by, for example, an increase in the value added tax (by approximately 100\%), an increase in real interest rates (by about 1-2 percentage points) and changes in the structure of non-tariff barriers to trade. Given the common conclusion of the mentioned economic studies and using the calculations of UBS (2000) that real consumption per capita would have to be higher by $1.2 \%$ annually in period 2 in order to compensate for the adjustment costs in period 1, the implied total economic adjustment costs in case of EU accession are approximately equal to 100 billion Swiss francs. ${ }^{15}$

15 This is calculated as the annuity of real consumption of approx. 330 billion Swiss Francs (in the year 2006), assuming a discount rate of $3-4 \%$. 
Figure 2: Derived Economic Adjustment Costs

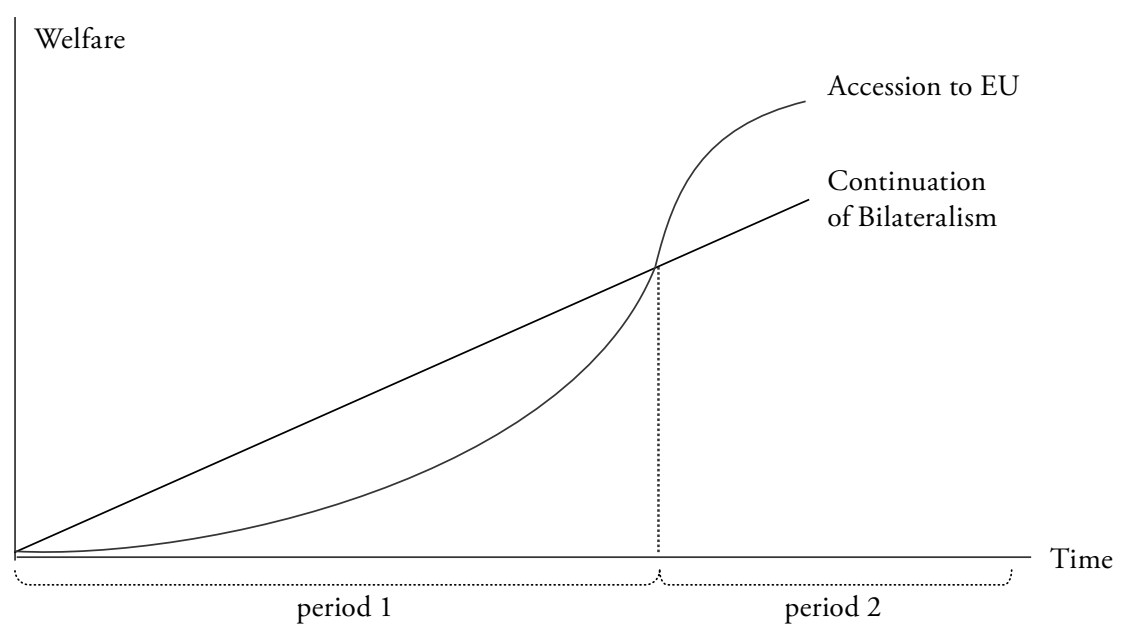

Source: Own Figure, following MüLlER and Nieuw Koop (1999), p.Z-3

Important elements of the political adjustment costs are adjustments of Swiss direct democracy, federalism and neutrality and the loss of sovereignty in some political areas. ${ }^{16}$ Even though one could argue that a change in these factors should be captured by the annual costs and benefits, we assume that Swiss citizens may get used to a change of these factors in the long term. Thus, we consider these adjustments as one-time adjustment costs over, for example, a period of 10 years. To get a first estimate of the magnitude of the political adjustment costs, we focus on one of these items, i.e. the adjustment costs associated with a loss of the direct democratic influence by the Swiss people. We use the estimation by FreY and STUtzer (2002) who found that, based on Swiss data on the cantonal level and controlling for many variables such as income or education, Swiss people's

16 Due to the direct participation Swiss voters have the ultimate agenda setting power on the national level (Frey, 1994, p. 341). Loosing some of this power may be regarded as costly, at least from the perspective of the electorate. As shown in a study over the period of 1.1.1993 to 30.6.1998 by EPINEY et al. (1998), there would have been a potential conflict between political decisions of Swiss people and the Community Law of the EU in about one fifth of the cases. As the EU has increased the competencies on the federal level this ratio may have increased in the meantime (see Freiburghaus, 2003, p. 14). Also, an EU membership would require considerable adjustments in the allocation of executive power between communities, cantons and the federal level in a number of areas, e.g. in education and health care (see Aussenpolitische Kommission des Ständerates, 2002, p. 20). 
level of satisfaction rises with their direct democratic participation: "the marginal effect of direct democratic rights on happiness is as large as the effect of living in the second-bottom income category (Swiss francs 2,000-3,000) instead of the bottom income category (under Swiss francs 2,000)" (p. 143). A marginal effect is defined as a change in a broad index that describes the possibility to exercise direct democratic rights. Thus, we interpret their findings as a form of compensating variation: a marginally lower index of democratic rights would have to be compensated by an average income of 1,500 Swiss francs per month in order to keep constant people's overall utility or "happiness". ${ }^{17}$ Assuming that the Swiss electorate of approximately 4.8 million voters considers an accession to the EU as a marginal decrease in their democratic influence, Swiss voters would have to be compensated by 7.2 billion Swiss francs per month or 86 billion Swiss francs annually to be as "happy" as before. ${ }^{18}$ Assuming an adjustment period over 10 years, this is equal to what may be a surprisingly large amount of 860 billion Swiss francs. ${ }^{19}$

Overall, the economic and especially political adjustment costs of an EU accession of a country such as Switzerland with a GDP of approximately 450 billion Swiss francs may well be quite sizeable. Note that the figures of approximately 100 billion per year over a period of 10 years or of 1000 billion in total do not include adjustment costs from a change in the other political factors (i.e. neutrality and federalism) or costs from the loss of, e.g., monetary policy.

\subsection{Net Annual Economic and Political Benefits}

Proposition 1 states that higher net annual economic and political benefits reduce the value to wait.

There are positive economic effects from a further mutual integration of the markets for goods, services and factors of production. Negative effects include the net transfer of Switzerland as a net payer to the EU. As mentioned in Subsection 4.1., the net annual economic benefits are expected to be positive, at least in the long term. The various studies estimate a long-term level effect of approximately $1 \%$ of Swiss GDP (MüLler and Nieuw Koop, 1999; LEA, 1999). ${ }^{20}$

17 This assumes that the income distribution in the categories is uniformly distributed.

18 See also Frey and Stutzer (2007) that supports our interpretation of their results.

19 See SpIRIg (2007) for sensitivity analyses.

20 Note that these studies usually do not include the loss of seigniorage due to the integration of Switzerland in the EMU that are estimated at approximately 300 to 500 million Swiss francs per year. This loss would be the third largest in absolute terms among the members of the EMU and four times higher than Germany's loss in relative terms (see FISCHER, JORDAN and LACK, 2002, p. 79). 
Regarding the net annual political benefits a key argument of the proponents of a full integration to the EU is that Switzerland would be able to affect decisions made in the EU - and not only to discuss them. Thus, the net annual political benefits would be the product of the size of this marginal effect times the value of it for Switzerland. We briefly consider the first element. As a first step towards assessing the political influence we can use power indices such as the Normalized Banzhaf Index $(\mathrm{NBI})^{21}$. This index measures the power of a single player to break an otherwise winning randomly constituted coalition on a random issue. The NBI is commonly used in the analysis of the impact of individual members in the Council of Ministers in the EU. ${ }^{22}$ To get a first impression of how powerful Switzerland would have been as an EU member we simulated Swiss membership and calculated the NBI for Switzerland, i.e. $\mathrm{NBI}^{\mathrm{CH}}$. It turns out that, in today's EU, the $\mathrm{NBI}^{\mathrm{CH}}$ for Switzerland as the 28 th member is $3 \%$, given that the threshold for a qualified majority stays roughly constant. In other words, in about one of 30 issues Switzerland could be expected to influence the decision. Table 1 shows the simulated $\mathrm{NBI}^{\mathrm{CH}}$ for a Swiss membership since the starting of the European Integration in $1957^{23}$

The results in Table 1 show that the hypothetical Swiss influence decreases over time from $11 \%$ in 1957 to $3 \%$ in 2007; this is expected because of the steadily rising number of EU members. Note that the NBI (without Switzerland) for a large country such as Germany can be calculated to equal $23.8 \%$ in 1957, falling to around $8 \%$ in 2007, whereas the NBI for the Netherlands decreased from $14.3 \%$ (1957) to around 3.5\% (2007). ${ }^{24}$ In relative terms, the smaller countries lost more power than the big countries. Nevertheless relative to their population smaller countries are still disproportionately represented. It is likely that, in future, the power of an individual country will further decrease. As the focus on random coalitions is somewhat restricting, some may argue that small countries can have a disproportional influence in certain areas. This is more probable if a country takes a position at or near the median on the issue in question. However, a first analysis shows that Switzerland's influence in certain important policy

21 For a good overview of the theory see Felsenthal and Machover (1998).

22 See e.g. Felsenthal and Machover (1998, 2005), Baldwin and Widgren (2003, 2004, 2005), KAUPPI and WidgREN (2004). There is some methodological controversy about whether the use of power indices is an appropriate procedure to analyse the power in the Council of Ministers (see e.g. Tsebelis and Garett, 1996 or Holler and Widgren, 1999).

23 The calculations are performed using own prepared datasets in the IOP 2.0 software offered by Prof. Thomas Bräuninger (University of Konstanz), downloadable at http://www.tbraeuninger.de/download.html.

24 For the NBI numbers for 1957 compare Felsenthal and Machover (1998). 
Table 1: Simulated $\mathrm{NBI}^{\mathrm{CH}}$ of Swiss Membership

\begin{tabular}{ccccccccc}
\hline & 1957 & 1973 & 1981 & 1986 & 1995 & 2004 & 2007 & EU30* \\
\hline $\mathrm{NBI}^{\mathrm{CH}}$ & $11.11 \%$ & $8.20 \%$ & $6.76 \%$ & $6.19 \%$ & $4.50 \%$ & $3.18 \%$ & $3.00 \%$ & $2.73 \%$ \\
\hline
\end{tabular}

Source: Own calculations based on the IOP 2.0 software offered by Prof. Thomas Bräuninger at http://www.tbraeuninger.de/download.html.

*Incl. Turkey and Croatia

Note: The hurdle for a qualified majority voting (QMV) in the Council in the EU-27 today is set at 255 votes out of $345(73.9 \%)$. Furthermore a winning coalition must represent a majority of members (15) and has to represent at least $62 \%$ of the EU population.

The hurdle for a QMV with Swiss membership is set in a way that the percentage of votes needed for a QMV stays roughly constant. Concretely, the hurdle is 262 votes out of 355 (73.8\%) in case of the EU-27 plus Switzerland. Switzerland is weighted with 10 votes (same as Austria and Sweden). With Swiss membership in the EU-6, the hurdle was set at 14 votes out of 19 and Switzerland was weighted with 2 votes [in the EU-9 the figures are $(44 / 62,5)$, in the EU-10 $(47 / 67,5)$, in the EU-12 $(57 / 80,5)$, in the EU-15 $(65 / 91,5)$ and in the EU-25 $(239 / 331,10)]$. In a possible future EU-30 plus Switzerland, the hurdle is 289 out of 391 (Turkey is weighted with 29 and Croatia with 7 votes).

areas (e.g. in monetary policy or in labour market policies) is even smaller than suggested by the general $\mathrm{NBI}^{\mathrm{CH}}$. This is due to a high distance of the Swiss position to the EU median position in a number of selected areas. ${ }^{25}$

Overall, the net annual benefits are positive, but may - with respect to the impact of a small country on the decisions made in the EU - be commonly overestimated.

\subsection{Uncertainty}

Proposition 1 states that an increase in the uncertainty of the annual benefits raises the value of waiting. Note that the EU acts as a legislator and adds a new state level to the member countries. EU law breaks national law and is binding in the areas where it applies. Economic benefits from accession are, therefore, high or low depending on what areas and in what regulative style the EU regulates. Let us emphasize three sources of uncertainty in the legislative procedure of the EU. ${ }^{26}$

25 See SPIRIG (2007) who performs a preliminary analysis of connected coalitions with simulated Swiss membership in important policy areas. See HösLI (2002) for a use of this methodology to formally combine the power indices with country-specific preferences. The results show the so called Modified Banzhaf Index (MBI), which is usually greater than the NBI in the range around the median position. It is not necessary that the median-member gains the most.

26 The EU has different instruments at hand to implement policies (treaties, secondary legislation like regulations, directives and decisions and also non-binding acts). We use the term "regulations" for simplicity to summarize the legislative actions by EU institutions. 
First, note that the primary law of the EU, the treaties, constitute the basis for $\mathrm{EU}$ institutions to get active in the legislative and executive process. Economic analyses of the treaties show that the $\mathrm{EU}$, in principle, is able to get active in any policy area. This is per se a problem as it offers the opportunity for excessive legislation on the supranational level (see, e.g., Alesina, Angeloni and Schuknecht (2005, p. 279)). One provision to extend the influence of the EU in its supranationality is article 308 of the EC Treaty which states that the EU may get active in any policy area if it is necessary to "achieve the goals" set in the treaties. ${ }^{27}$ As the goals are only broadly defined, this article has been extensively used to adopt and defend new legislations in the past. ${ }^{28}$ This so-called "flexibility clause" has also been adopted in the proposal for a European Constitution in article I-18, would apply to larger set of areas and is likely to be incorporated in any revised version of the European Constitution. This also applies to the Reform Treaty drafted in autumn 2007 as a potential substitute for the Constitutional Treaty. Thus, the broader the legislative basis is or may become, the broader the range of potential regulations to expect and, therefore, the bigger the spread between the best and the worst regulative outcome.

The second source of uncertainty is the "passage probability" of a legal act in the Council of Ministers. Note that the number of legislations typically rises with an increase of this probability. From the voting analysis briefly described in Subsection 4.2., one can calculate the passage probability of a random proposition in the Council of Ministers which, de facto, is the most important institution in the EU to pass legal acts. BALDwIN and WIDGREN (2003) showed that this probability steadily decreased from 1957 to 2004 . However, their analysis also implies that the proposal for a European Constitution would increase this passage probability and therefore would make it "dramatically easier to pass EU legislation" (p.7). As our preliminary assessment shows, the new Reform Treaty seems to roughly adopt the same decision procedure. ${ }^{29}$ Both the Constitutional and the Reform Treaty are thus likely to include a voting scheme with a higher passage probability. Also note that the Constitutional Treaty proposed a so called

27 In the Treaty of Rome it was article 235.

28 In the first half of the 90s the Commission and the Council used this Article over 30 times in each year (see VAubel, 2001, p. 122). The importance of this article for the shift of competences is reported in Begg et al. (1993), Vaubel (1994b, 2001), Gerken et al. (2002) and Gerken and Schick (2003).

29 In order to pass a legislation, $55 \%$ of the countries that represent $65 \%$ of the citizens have to vote for the proposal. However, there is a special condition for a blocking minority which tends to somewhat increase the power of the small members. See: http://www.consilium.europa.eu/ cms3_fo/showPage.asp?id=1317\&lang=en 
"passerelle clause" (article 444) that allows the European Council to switch the law-making procedure from unanimity to majority voting in certain areas without seeking agreement (referenda or ratification) by the member states. Such a switch, however, requires an unanimous decision by the European Council and must be approved by the European Parliament and all the national parliaments. ${ }^{30}$ The Reform Treaty adopts this passerelle clause. Note that the passerelle clause is a one-way concept; a (re-)switch from QMV to unanimity is not foreseen. Thus a higher passage probability and the possibility to switch from unanimity to QMV, both of which are associated with the Constitutional Treaty and the Reform Treaty, make future legislation less predictable. This can be seen as a source of (increasing) uncertainty.

The third source of uncertainty arises from the lack of horizontal and vertical institutional safeguards that prevent an excessive use of power of EU institutions and/or an excessive shift of tasks from member states to the supranational level. A horizontal institutional safeguard could be seen in a strict separation of powers at the EU level. Vertical institutional safeguards to prevent endogenous centralisation are, for example, democratic instruments in the hand of the citizens to control their representatives. Economic analyses have shown that the institutional framework in the EU is vulnerable to excessive centralization and characterized by some "democratic deficit". ${ }^{31}$ According to these analyses, the European Commission has a monopoly power in initiating legislature, the European Parliament still plays more the role of an observer than of a decision maker and the European Court of Justice (ECJ) seems to have a role as a promoter of integration and to be less concerned about centralisation. Also, the members of the Council of Ministers have some interests in shifting the most controversial legislation from their home countries to the EU level. Given these institutional particularities, it is not surprising that - in the light of a number of economic analyses - the EU acquired competences in areas that should be left to the member states. ${ }^{32}$

30 See BALdwin and Wyplosz (2006, p. 68) who argue that these constraints are unlikely to serve as a major obstacle because the leaders in the European Council are the leaders in their national parliaments and because a switch to majority voting also increases the power of the European Parliament.

31 For an analysis of the incentives of EU institutions and the tendency towards centralization see Vaubel (1994, 1996, 1997, 2001, 2006), Berglöf et al. (2003), Eichenberger (1994) and BALDWIn et al. (2001). For an empirical analysis of the preferences of the EU institutions, see Mattila (2004) and Kaendig and Selck (2005).

32 See e.g. Alesina, Angeloni and Schuknecht (2005), Alesina and Perrotti (2004), Alesina and Wacziarg (1999), Begg et al. (1993), Dewatripont et al. (1995), Gerken and Schick (2003), SApir et al. (2003), Vaubel (1994, 1997, 2001). 
Overall, the existence of the flexibility and the passerelle clause, the likelihood of an increase in the so-called passage probability as well as the institutional particularities of the EU with low safeguards against an accumulation of power on the supranational level imply a large spread of net annual benefits for a potential member country. Of course, it is possible that the EU leaders use their power wisely. However when it comes to the crunch economists tend to rely on credible rules more than on the moral attitude of wise politicians. Thus uncertainty may well have increased in the past, given the empirically observed regulative centralization in the EU and may well not decrease in the future given some of the features of the new Reform Treaty. ${ }^{33}$

\subsection{Probability of the Good State of Nature}

Proposition 3 states that the value of waiting decreases with an increase in the probability of the good state of nature (if the value of waiting is positive).

The probability of the good case is highly dependent on the outcome of the decision process of the EU, in particular on the probability of good decisions by the Council of Ministers. As some argue that highly regulated EU-members may impose their regulation level on other members (see VAUBEL, 2006), one way of analyzing the likelihood of good decisions to arrive is to focus on the coalition building in the Council of Ministers. A possible criteria to identify high-regulation coalitions is to look at the "legal origin" of countries as other studies have shown that there is a close relationship between "legal origin" and "regulative style". We can sort the EU member countries due to their legal origin and calculate all possible coalitions between the groups of countries with the same legal origin. ${ }^{35}$ It turns out that the high-regulation coalition (i.e. the countries with French legal origin) had the possibility to dominate the decision process especially in the beginning of the European integration. In fact, this coalition was able to form a simple majority in the legislative preparation in the commission from 1957 to 2004 . In the council, this coalition had the power to find a qualified majority until 1973. Throughout the integration process it is not possible to find a qualified majority in the council against this high-regulation coalition.

33 There are some other institutional changes proposed in the Reform Treaty that may reduce uncertainty in the future. We will address the details of the Reform Treaty in our future research.

34 See Botero et al. (2004) and Djankov et al. (2002, 2003a,b); note that there are five possible legal origins: English, German, French, Socialist and Scandinavian.

35 The following draws on SPIRIG (2007) who computes a preliminary analysis of possible coalitions based on the legal origin in the EU. 
Even if all other members voted together, the high-regulation coalition has had a blocking minority. ${ }^{36}$

\section{Alternative Integration Possibilities and Experiences of Other Countries}

The value of waiting highly depends on the alternative scenario which an accession to the $\mathrm{EU}$ is compared with. In the following, we give a short overview of how the options changed over time for Switzerland and then try to compare the Swiss behaviour with that of other similar countries.

In the beginning of the European integration project in 1957, Switzerland showed only minor interest in joining the European Community (EC). It had no interests in coal or steel industry and it was not directly involved in rebuilding the economy after the war as its infrastructure was intact. The discrimination costs of staying outside and, therefore, the potential net benefit of membership to the EC were quite low. As the EC-6 started to increasingly liberalize its internal market founding a customs union, the discrimination costs grew which pushed the outsider countries to the foundation of the European Free Trade Area (EFTA) in $1960 .{ }^{37}$ As the EC further integrated their markets, members of the EFTA attempted to reduce the increasing economic disadvantages for outsider countries. Whereas countries like the UK increasingly favoured a membership to the EC, Switzerland established a Free Trade Agreement (FTA) with the EC in 1972. In 1973, Denmark, Ireland and the UK joined the EC. Other countries such as Greece, Portugal and Spain followed with the creation of the common market.

Again, a further possibility was created for Switzerland and other hesitating countries: the European Economic Area (EEA). However, the Swiss electorate turned down an EEA-membership on December 6th 1992 with 50.3\% of the votes, even though the government and the parliament highly recommended this membership. ${ }^{38}$ Even though some believed at the time that an EU membership

36 Since the latest enlargement the coalition of Socialist legal origin countries also has a blocking minority. Until 2007 only the French legal origin coalition had that "privilege".

37 See BALDWIN (1995) for this "domino theory" of integration that found empirical support by SAPIR (2001) for the EFTA countries. Austria, Denmark, Norway, Portugal, Sweden, Switzerland and the UK were the founding members in 1960.

38 Note that 16 of 26 cantons voted "No"; therefore, the required simple majority of the cantons (“Ständemehr") was clearly missed. 
would now become more likely, history took an interesting turn. In February 1993, the Swiss government asked the EU for bilateral negotiations in 15 areas. In November 1993, the Council of Ministers decided to enter bilateral negotiations with Switzerland in four of the 13 proposed and in two new areas. This was the starting point for the bilateral path for Switzerland that lead to the Bilateral Agreements I and II in 1999 and 2004, respectively. Thus, every time the pressure to join the EU was increasing, alternative options of regional integration or cooperation emerged that reduced the disadvantage of being an outsider country.

GstöHL (2002) tries to explain delayed accession of countries like Austria, Denmark, Finland, Ireland, Sweden and the UK and argues that the "stubborn" countries Norway, Sweden and Switzerland were characterized by high political impediments to integration (p. 532) which distinguished them from the other mentioned countries. "A country is likely to be less stubborn the higher the expected economic benefits and the weaker the domestic and geo-historical identity constraints" (GstöHL 2002, p. 545). The analysis shows that there was a decisive difference between Sweden that joined the EU in 1995 and Norway and Switzerland, on the other hand. For the Swedes, the accession to the EU was seen as a way to "protect their national identity" and, most importantly, Sweden was in an economic crisis at that time (see GstöHL 2002, p. 544). This argument is in line with our analysis that stresses the high political adjustment costs in case of Switzerland. However, we prefer the neutral expression of a rational "waiting" to the notion of "stubbornness".

\section{Conclusions}

This paper interprets the decision of a country to join a supranational institution as an investment with sunk adjustment costs and uncertain pay-offs. This implies that immediate accession may not be optimal despite of the fact that the net present value of accession is greater than zero. As the net benefits are subject to uncertainty and thus may turn out to be high or low in a later period, waiting has a value because it allows staying outside of the supranational institution in case the net benefits are low. This value of waiting has to be taken into account in the starting period the country makes the decision.

Based on a simplified two-period model, we identify the main determinants of the value of waiting and use the framework to analyze the case of Switzerland. We find preliminary evidence that political adjustment costs may be substantial, whereas the political benefits of membership may be rather small for Switzerland. 
Also, the high and possibly increased degree of uncertainty of the political process and outcome in the EU, together with the alternative integration options that Switzerland faced throughout history, is an important element in the assessment. Taking into account that economic adjustment costs and annual benefits of an accession seem to compensate each other as noted by a number of economic studies, our analyses of the political elements of an accession to the EU may help to explain Switzerland's behaviour with respect to an EU membership.

The approach presented in this paper could of course be extended. Even though the fundamental findings of the simple 2-period model do hardly change if a continuous time model is applied - the main reason why we use the simple version -, the more complex models would offer a more detailed and refined determination of the optimal timing of accession. Furthermore it may be important to link the model more carefully with a potential candidate's political and economic environment by using more comprehensive quantitative analyses. A very interesting extension of the approach would be to take into account strategic behaviour of the supranational institution (or its members) and possibly the acceding country. This would allow to deepen the analysis of potential risks that are associated with waiting. Finally, even though the model is based on the idea that overall benefits and costs play an important role in the decision to join, the approach might also shed light on the behaviour of special interest groups and their interaction in the political process.

\section{Appendix: Sign of the First Derivative of $W$ with Respect to $p$.}

From Equation (6) we know that $W>0$ if the following inequality is fulfilled:

$$
\left(1-\frac{p}{1+i}\right) I-p V_{t}^{H}-\frac{(1-p)(1+i)}{i} V_{t}^{L}>0 .
$$

Equation (8) reveals that $\partial W / \partial p<0$ if the following inequality applies:

$$
-\frac{I}{1+i}-V_{t}^{H}+V_{t}^{L}\left(\frac{1+i}{i}\right)<0 .
$$

Rewriting (A1) and (A2) appropriately leads to the following inequalities, respectively: 


$$
\frac{1+i-p}{(1-p)(1+i)} I-\frac{p}{(1-p)} V_{t}^{H}>\frac{1+i}{i} V_{t}^{L}
$$

and

$$
\frac{1}{(1+i)} I+V_{t}^{H}>\frac{1+i}{i} V_{t}^{L}
$$

Note that if the term on the left hand of (A3) is smaller than the left-hand term of (A4), $W>0$ is a sufficient (albeit not necessary) condition for $\partial W / \partial p<0$; in this case, (A4) and thus $\partial W / \partial p<0$ is a fortiori true. In order to see whether this is indeed the case, we subtract the second term from the first one and then determine the sign. Thus,

$$
\frac{1+i-p}{(1-p)(1+i)} I-\frac{p}{1-p} V_{t}^{H}-\frac{1}{1+i} I-V_{t}^{H}
$$

Expanding and collecting terms leads to the following result:

$$
I\left[\frac{i}{(1-p)(1+i)}\right]-V_{t}^{H} \frac{1}{1-p}=\frac{i}{(1-p)}\left[\frac{I}{1+i}-\frac{V_{t}^{H}}{i}\right] .
$$

Note that a necessary condition for $W>0$ is that the $N P V_{H}$ in equation (2) is greater than zero. This implies that $V_{t}^{H} / i>I /(1+i)$. But if this condition holds, equation (A5) must be smaller than zero. Therefore, $W>0$ is a sufficient condition for $\partial W / \partial p<0$.

q.e.d.

\section{References}

Aussenpolitische Kommission des Ständerates (2002), „Die Optionen der schweizerischen Integrationspolitik“, mimeo.

Alesina, Alberto and Romain Wacziarg (1999), "Is Europe Going too Far?", Carnegie-Rochester Conference Series on Public Policy, 51, pp. 1-42.

Alesina, Alberto, Ignazio Angeloni and Ludger Schuknecht (2005), "What Does the European Union Do?", Public Choice, 123, pp. 275-319. 
Alesina, Alberto and Roberto Perrotti (2004), “The European Union: A Politically Incorrect View”, Journal of Economic Perspectives Winter, Vol. 18, pp. 26-48.

Baldwin, Richard E. (1994), Towards an Integrated Europe, Centre for Economic Policy Research, CEPR, London.

Baldwin, Richard E. (1995), "A Domino Theory of Regionalism", in: Baldwin, R. E., Haapranta, P., Kiander, J. (eds), Expanding European Regionalism: The EU's New Members. Cambridge Univ. Press: Cambridge.

Baldwin, Richard E., Erik Berglöf, Francesco Giavazzi and Mika WidGREN (2001), "Nice Try: Should the Treaty of Nice Be Ratified?", Monitoring European Integration 11, A CEPR annual Report.

Baldwin, Richard E. and Mika Widgren (2003), "Decision Making and the Constitutional Treaty: Will the IGC discard Giscard?", CEPS Policy Brief No. 37, August, Centre for European Policy Studies, Brussels.

Baldwin, Richard E. and Mika Widgren (2004), "Winners and Losers under Various Dual Majority Rules for the EU's Council of Ministers", CEPS Policy Brief, No. 50, April, Center for European Policy Studies, Brussels..

Baldwin, Richard E. and Mika Widgren (2005), "The Impact of Turkey's Membership on EU Voting", CEPS Policy Brief, No. 62.

Bärlocher, Jürg, Bernd Schips and Peter Stadler (1999), „Makroökonomische Auswirkungen eines EU-Beitrittes der Schweiz", Bundesamt für Wirtschaft und Arbeit (BWA) Schriftenreihe, Beiträge zur Wirtschaftspolitik, Nr. 6. KOF-Studie.

Begg, David, Jacques Crémer, Jean-Pierre Danthine, Jeremy Edwards, Vittorio Grilli, Damien Neven, Paul Seabright, Hans-Werner Sinn, Anthony Venables and Charles Wyplosz (1993), "Making Sense of Subsidarity: How much Centralization for Europe?”, Monitoring European Integration 4, a CEPR Annual Report.

Begg, David, Olivier Blanchard, Diane Coyle, Barry Eichengreen, Jefferey Frankel, Francesco Giavazzi, Richard Portes, Paul Seabright, Anthony Venables, Alan Winters and Charles Wyplosz (2003), “The Consequences of Saying No', An Independent Report into the Economic Consequences of the UK Saying No to the Euro", mimeo.

Berglöf, Erik, Barry Eichengreen, Gerard Roland, Guido Tabellini and Charles Wyplosz (2003), "Built to Last: A Political Architecture for Europe", Monitoring European Integration 12. Centre for Economic Policy Research.

Borner, Silvio and Frank Bodmer (2004), Wohlstand ohne Wachstum. Eine Schweizer Illusion, Zürich. 
Botero, Juan C., Simeon Djankov, Rafael La Porta, Florencio Lopez-deSilanes and Andrei Shleifer (2004), "The Regulation of Labor", Quarterly Journal of Economics, Volume CXIX, Issue 4, pp. 1339-1382.

BräUninger, Thomas and Thomas König (2005), Indices of Power IOP 2.0, Computer Programm, Universität Konstanz, http://www.tbraeuninger.de/ iop.html

Brunetti, Aymo, Markus Jaggi and Rolf Weder (1998), „Umverteilungswirkungen einer wirtschaftlichen Öffnung und Abstimmungsverhalten: Eine Analyse am Beispiel des Schweizer EWR-Entscheids“, Schweizerische Zeitschrift für Volkswirtschaft und Statistik, Vol. 134 (1), pp. 63-91.

Cecchini, Paolo (1988), Europa '92, Baden-Baden.

Dewatripont, Mathias and Gerard Roland (1995), "The Design of Reform Packages under Uncertainty”, American Economic Review, Vol.85, No. 5, pp. 1207-1223.

Dewatripont, Mathias, Francesco Giavazzi, Jürgen von Hagen, Ian Harden, Torsten Persson, Gérard Roland, Howard Rosenthal, André Sapir and Guido Tabellini (1995), "Flexible Integration, Towards a More Effective and Democratic Europe", Monitoring European Integration 6, A CEPR annual Report.

Dixit, Avinash and Robert Pindyck (1994), Investment under Uncertainty, New Jersey.

Djankov, Simeon, Rafael la Porta, Florencio Lopez-de-Silanes, and Andrei SHLeifer (2002), “The Regulation of Entry”, Quarterly Journal of Economics, CXVII, pp. 1-37.

Djankov, Simeon, Edward Glaeser, Rafael la Porta, Florencio LopezDe-Silanes, and Andrei Shleifer (2003a), "The new Comparative Economics", Journal of Comparative Economcis, 31, pp. 595-619.

Djankov, Simeon, Rafael la Porta, Florencio Lopez-de-Silanes, and Andrei Shleifer (2003b), "Courts", Quaterly Journal of Economics, CXVIII, pp. 457-522.

Eichenberger, Reiner (1994), "The Benefits of Federalism and Risk of Overcentralization”, Kyklos, Vol.47, Fasc. 3, pp.403-420.

Epiney, Astrid, Karine Siegwart, Michael Cottier and Nora Refaeil (1998), Schweizerische Demokratie und Europäische Union, zur demokratischen Legitimation in der EU und den Implikationen eines EU-Beitritts für die schweizerische Demokratie, Bern.

Felsenthal, Dan S. and Moshé Machover (1998), The Measurement of Voting Power, Theory and Practise, Problems and Paradoxes, Cheltenham Glos UK. 
Felsenthal, Dan S. and Moshé Machover (2005), "Qualified Majority Voting Explained", Mimeo in the Voting Power and Procedures Project, CPNSS, LSE.

Fischer, Andreas M., Thomas J. Jordan and Caesar P. Lack (2002), "Giving Up the Swiss Franc: Some Considerations on Seigniorage Flows under EMU", Schweizerische Zeitschrift für Volkswirtschaft und Statistik, 38, pp. 61-82.

Freiburghaus, Dieter (2003), „Die special relations zwischen der Schweiz und der Europäischen Union“, Working Paper de l'IDHEAP 3/2003.

Frey, Bruno S. (1994), "Direct Democracy: Politico-Economic Lessons from Swiss Experience”, American Economic Review, Vol. 84, No. 2, pp. 338-342.

Frey, Bruno S. and Alois Stutzer (2002), Happiness and Economics, Princeton and Oxford.

Frey, Bruno S. and Alois Stutzer (2007), "Economic Consequences of Mispredicting Utility", Mimeo (October).

Gerken, Lüder, Jörg Märkt, Gerhard Schick and Andreas Renner (2002), Eine Freiheitliche supranationale Föderation - Zur Aufgabenteilung in Europa, Integration Europas und Ordnung der Weltwirtschaft, Baden-Baden, Band 26, Hrbek Rudolf, Oppermann Thomas and Joachim Starbatty (eds).

Gerken, Lüder and Gerhard Schick (2003), „Wege zur europäischen Verfassung I: Wer garantiert die Subsidiarität?", Stiftung Marktwirtschaft, Frankfurter Institut, Nr. 75.

Gstöhl, Sieglinde (2002), "Scandinavia and Switzerland: Small, Successful and Stubborn towards the EU", Journal of European Public Policy 9:4, pp. 529-549.

Haubrich, Joseph G. and Jospen A. Ritter (1999), "Committing and Reneging: A Dynamic Model of Policy Regimes", International Review of Economics and Finance, 13 (1), pp. 1-18.

Hauser, Heinz and Sven Bradke (1992), EWR-Vertrag, EG-Beitritt, Alleingang, Wirtschaftliche Konsequenzen für die Schweiz, Schweizerisches Institut für Aussenwirtschafts-, Struktur- und Regionalforschung (SIASR), Chur/ Zürich.

Holler, Manfred and Mika Widgren (1999), "Why Power Indices for Assessing European Union Decision-Making?”, Journal of Theoretical Politics, 11(3), pp.321-330.

Hösli, Madeline O. (2002), "Preferences and Power in the European Union", Homo Oeconomicus XIX (3), pp.311-326.

Kaendig, Michael and Torsten J. Selck (2005), "Mapping Out Political Europe: Coalitions Patterns in EU-Decision-Making", International Political Science Review, Vol.26, No. 3, pp.271-290. 
Kauppi, Heikki and Mika Widgren (2004), "What Determines EU Decision Making? Needs, Power or Both?”, Economic Policy, July, pp. 221-266.

LABORATOIRE D'ÉCONOMIE APPLIQUÉE (LEA) (1999), «Effets à long terme d'une intégration de la Suisse à Europe - résultates tirés d'un modèle en équilibre général calculable», University of Geneva.

Mattila, Miкко (2004), "Contested Decisions: Empirical Analysis of Voting in the European Union Council of Ministers", European Journal of Political Research, 43, pp. 29-50.

McDonald, Robert and Daniel Siegel (1986), "The Value of Waiting to Invest", The Quarterly Journal of Economics, 101, Issue 4, pp. 707-728.

Müller, André and Renger van Nieuw koop (1999), „EU-Integration der Schweiz: Wirtschaftliche Auswirkungen, Ergebnisse eines berechenbaren Mehrländer-Gleichgewichtsmodelles für die Schweiz“, BWA Schriftenreihe, Beiträge zur Wirtschaftspolitik Nr. 8, Bundesamt für Wirtschaft und Arbeit (BWA).

Sapir, Andre (2001), "Domino Effects in Western European Regional Trade, 1960-1992", European Journal of Political Economy, Vol. 17, pp. 377-388.

Sapir Andre, Philippe Aghion, Giuseppe Bertola, Martin Hellwig , Jean Pisani-Ferry , Dariusz Rosati , Jose Vinals and Helen Wallace (2003), An Agenda for a Growing Europe, Making the EU Economic System Deliver. Report of an Independent High-level Study Group established on the initiative of the President of the European Commission.

Socialist Democratic Party (2006), „Neue Europa-Plattform“, mimeo.

Spirig, Beat (2007), „Die Europäische Integration vor dem Hintergrund eines EU-Beitritts der Schweiz, Eine Politökonomische Analyse“, Dissertation, University of Basel.

Swiss Federal Council (1999), „Schweiz-Europäische Union: Integrationsbericht 1999“.

Swiss Federal Council (2006), „Europabericht 2006“, www.europa.admin.ch Swiss People’s Party (2005), „13 Jahre nach dem EWR: Chance Schweiz: Stärke durch Unabhängigkeit", Delegiertenversammlung in Suhr vom 3. Dezember 2005, mimeo.

Tsebelis, George and Geoffrey Garett (1996), "Agenda Setting Power, Power Indices, and Decision Making in the European Union", International Review of Law and Economics, 16, pp.345-361.

UBS (2000), „Alleingang - Bilaterale Verträge - EU-Beitritt. Implikationen für die Schweizer Wirtschaft und den Finanzplatz Schweiz", UBS Group Economic Research Studies. 
Vaterlaus, Stephan, Margit Himmel, Christoph Koellreuter and Banu Simmons-SÜER (1999), "Alternative EU-Integrationsszenarien der Schweiz, Wirtschaftliche Auswirkungen gemäss dem BAK-Makromodell”, BWA Schriftenreihe, Beiträge zur Wirtschaftspolitik Nr. 7, Bundesamt für Wirtschaft und Arbeit (BWA).

Vaubel, Roland (1994a), "The Public Choice Analysis of European Integration: A Survey", European Journal of Political Economy, 10, pp.227-249.

Vaubel, Roland (1994b), "The Political Economy of Centralization and the European Community”, Public Choice, 81, pp. 151-190.

Vaubel, Roland (1996), "Constitutional Safeguards Against Centralization in Federal States. An International Cross-Section Analysis", Constitutional Political Economy, 7, pp. 79-102.

Vaubel, Roland (1997), "The constitutional reform of the European Union", European Economic Review, 41, pp.443-450.

Vaubel, Roland (2001), Europa-Chauvinismus. Der Hochmut der Institutionen, München.

Vaubel, Roland (2007), "Die Politische Ökonomie der Sozialpolitischen Regulierung in der Europäischen Union", in: Klaus Heine, Wolgang Kerber (eds), Zentralität und Dezentralität von Regulierung in Europa, Stuttgart, pp. 237-260.

\section{SUMMARY}

Why do some countries join the EU earlier than others, why do others wait? In order to address this question we apply the theory of investment under uncertainty (Dixit and Pindyck, 1994) to the decision on EU-membership. We present the idea in a simplified model of two periods to study how the value of waiting depends among other things on the expected benefits, the degree of uncertainty and the adjustment costs. The approach gives rise to a country's position to deliberately postpone a membership in order to keep the option to join later if this is desirable. The model, thus, may explain delayed accession to the EU. We apply this framework to Switzerland by quantifying some of the crucial determinants of the value of waiting and qualitatively compare these findings with the experiences of other countries. We find evidence that adjustment costs are relatively high for Switzerland whereas net annual benefits are limited and subject to an increased degree of uncertainty. 